DOI https:// doi.org/10.32837/app.v0i64.202

УДК 341

Пасечник О. В. * (НУ «ОЮА»)

ORCID ID: https://orcid.org/0000-0002-2032-1851

\title{
СТАНДАРТИ ОРГАНІЗАЦІЇ ОБ'СДНАНИХ НАЦІЙ У СФЕРІ ТРАНСПЛАНТАЦІЇ ОРГАНІВ I / АБО ТКАНИН, КЛІТИН
}

\section{UNITED NATIONS STANDARDS FOR ORGANS AND / OR TISSUES AND CELLS TRANSPLANTATION}

*Olena Pasechnyk - PhD in Law, Associate Professor at the Department of International and European Law, National University "Odesa Law Academy" (23, Fontanska Doroha St., Odesa, Ukraine).

Abstract

The article analyzes the universal level of legal regulation of transplantation of organs and / or tissues, cells within the United Nations. The United Nations soft law provisions in the field of organ and / or tissue transplantation have been investigated. The provisions of the UN General Assembly Resolution 71/322 "Enhancing and Promoting Effective Measures and International Cooperation in Organ Donation and Transplantation to Prevent and Suppress Trafficking in Human Organs and Trafficking in Human Organs" and of the General Assembly resolution 73/189 "Enhancing and Encouraging Effective Measures and International Cooperation in Organ Donation and Transplantation to Prevent and Stop Trafficking in Human Organs and Organ Trafficking" are disclosed. Modern challenges in international legal cooperation in the field of regulation of transplantation of organs and / or tissues and cells are considered. The article draws attention to the activities of the UN Special Rapporteur on trafficking in children, child prostitution and child pornography on transplantation of organs and / or tissues, cells. The provisions of the Optional Protocol to the Convention on the Rights of the Child on Trafficking in Children, Child Prostitution and Child Pornography of January 1, 2000, applicable to the transplantation of organs and/ or tissues, cells, are analysed. The proposal of the UN and the Council of Europe on the drafting of an international convention on the prohibition of trafficking 
in human organs and tissues is analysed. Transplantation of organs and / or tissues and cells has been proven to be a component in the exercise of the right to health, and can be one of the most serious human rights violations. From good to crime, these are two medals of the same phenomenon. These two radically different directions require mandatory international legal regulation for protection human rights from the right to health to the right to protection against arbitrary transplantation and organ trafficking. It is established that there are no binding norms in the field of transplantation of organs and / or tissues, cells.

Keywords: transplantation of organs and / or tissues, cells, United Nations, United Nations Commission on Crime Prevention and Criminal Justice, right to health.

Трансплантація органів і / або тканин, клітин один з дієвих способів надати медичну допомогу пацієнтам, для яких відсутні інші дієві форми лікування. Досягнення сучасної медицини дозволяють у багатьох випадках зберегти життя або поліпшити його якість, а одним з найбільш ефективних і реальних способів досягнення таких результатів є трансплантація (Совгиря, Янчук, 2018, с. 217). Враховуючи півстолітню еволюцію трансплантації органів і / або тканин, клітин, можливо виокремити суттєві прогалини. По-перше, відсутні універсальні міжнародно-правові зобов'язуючі норми у сфері трансплантації органів і / або тканин, клітин. По-друге, на національному рівні у деяких держав відсутнє правове регулювання щодо доступу, безпеки, якості трансплантації органів і / або тканин, клітин. По-третє, наявність транснаціональної контрабанди органів і / або тканин, клітин $з$ метою трансплантації.

На універсальному рівні відсутні зобов'язуючі норми у сфері трансплантації органів і / або тканин, клітин, але дане питання піднімалося на засіданнях Генеральної Асамблеї ООН. 8 вересня 2017 р. була прийнята резолюція 71/322 Генеральної Асамблеї ООН «Посилення і заохочення ефективних заходів і міжнародного співробітництва в сфері донорства та трансплантації органів 3 метою перешкоджати і протидіяти торгівлі людьми для вилучення органів і торгівлі людськими органами». У резолюції 71/322 зазначається, що торгівля людьми 3 метою вилучення органів і пов'язана з нею торгівля людськими органами є злочині і шкодять реалізації прав людини та основних свобод (Резолюция 71/322 «Усиление и поощрение эффективных мер и международного сотрудничества в сфере донорства и трансплантации органов с целью препятствовать и про- 
тиводействовать торговле людьми для изъятия органов и торговле человеческими органами», 2017).

У квітні 2006 р. у Відні проходило засідання Комісії ООН із запобігання злочинності та кримінального правосуддя, яка розглядала питання про міжнародне співробітництво в боротьбі з транснаціональною злочинністю, включаючи попередження незаконного обігу органів людини, боротьби з ним і покарання за нього. У Відні 27 травня 2016 року завершилася 25-я сесія Комісії з попередження злочинності та кримінального правосуддя, на якій з ініщіативи Республіки Білорусь була схвалена резолюція, спрямована на припинення незаконного обігу органів людини і торгівлі людьми 3 метою вилучення органів (В Вене по инициативе Беларуси принята резолюция ООН о пресечении торговли людьми с целью изъятия органов, 2016). У резолюції наголошується, що така злочинна практика частково підживлюється дефіцитом органів людини, що використовуються для трансплантащії. Комісії з попередження злочинності та кримінального правосуддя настійно закликала держави-члени боротися з незаконним обігом органів, запобігати їх несанкціонованому вилучення або трансплантації, незаконній купівлі-продажу. Важливо зазначити, що в Резолюції міститься заклик до держав-членів не залишати безкарними осіб, причетних до незаконної торгівлі органами людини, а також причетних до вилучення органів у біженців, що рятуються від конфліктів.

Метою трансплантації органів і / або тканин, клітин є реалізація права на здоров'я, прав пацієнтів, проте, торгівля людьми 3 метою вилучення органів і пов'язана 3 нею торгівля людськими органами $є$ порушенням основоположних прав людини, перш за все, права на життя, права на здоров'я, право на гідність та інших. Як вказує, Н. В. Хендель, що сфери суспільних відносин, які раніше були пріоритетними напрямами внутрішньодержавного правового регулювання, стали предметом міжнародно-правового регулювання у сфері охорони здоров' я через призму міжнародного права прав людини, а саме і захисту біомедичних прав людини до яких і відноситься сфера трансплантології (Хендель, 2014, с. 191).

У резолюції 71/322 пропонується посилити національне, регіональне і міжнародне співробітництво з метою ефективно перешкоджати і протидіяти торгівлі людьми для вилучення органів і торгівлі людськими органами завдяки наступним заходам:

1) держави-члени ООН повинні перешкоджати і протидіяти торгівлі людьми з метою вилучення органів і торгівлі людськими 
органами, керуючись своїми зобов'язаннями за міжнародним та національним правом, і домагатися дотримання встановлених норм шляхом прийняття таких заходів, які можуть включати попередження несанкціонованого вилучення або імплантації людських органів, їx незаконної купівлі-продажу, посередництва в такий купівлі-продажу та інших незаконних операцій з людськими органами;

2) розслідувати такі діяння та кримінально переслідувати винних у вчиненні таких злочинів і забезпечити покарання за них;

3) держави-члени ООН повинні ратифікувати Конвенцію Організації Об'єднаних Націй проти транснаціональної організованої злочинності і Протокол про попередження і припинення торгівлі людьми, особливо жінками і дітьми, і покарання за неї;

4) державам-членам необхідно: 4.1) удосконалити нормативноправову базу, шляхом ії перегляду, доопрацювання або виправлення, з метою перешкоджати і протидіяти торгівлі людьми для вилучення органів і торгівлі людськими органами; 4.2) прийняти належних законодавчих заходів, що дозволяють гарантувати, щоб донорство органів відбувалося $з$ дотриманням клінічних критеріїв та етичних норм, грунтувалося на усвідомленій і добровільній згоді донорів і здійснювалося як безкорисливий акт, без будь-яких грошових виплат або інших ресурсів, що має грошову цінність, що не виключає відшкодування розумних витрат, понесених донорами; 4.3) забезпечити рівний і недискримінаційний доступу до трансплантації людських органів, а також посилення усвідомлення і розуміння населенням тієї користі, яку приносить добровільне безоплатне надання органів від померлих і живих донорів, і тих фізичних, психологічних і соціальних ризиків, які створюють для окремих людей і для людських спільнот торгівля людськими органами та трансплантаційний туризм; 4.4) забезпечити, щоб вилучення людських органів у померлих і живих людей, а також трансплантація таких органів відбувалися виключно в пунктах, спеціально уповноважених відповідними національними відомствами охорони здоров'я, і не здійснювалися поза рамками вітчизняних трансплантаційних систем або в ситуаціях, коли трансплантація стане порушенням вищеназваних керівних принципів або ж національних законів або правил про трансплантацію; 4.5) розвивати і зміцнювати регулятивний нагляд за медичними установами і медичними фахівцями, що займаються трансплантацією людських органів, у тому числі за допомогою періодичні ревізії; 4.6) встановлювати визначені процедури і критерії для санкціонування 256 
кожної операції по вилученню та трансплантації органу; 4.7) створити регістри реципієнтів; 4.8) заохотити добровільне надання періодичної інформації у міжнародні регістри, де фіксується діяльність в сфері донорства та трансплантації органів, наприклад, в Глобальну обсерваторію 3 донорства та трансплантації, створену у співпраці з Всесвітньою організацією охорони здоров' я; 4.9) організувати довгостроковий медичний та психосоціальний догляду як за живими донорами, так і за реципієнтами;

5) обмінюватися державам-членам ООН досвідом та інформацією щодо попередження незаконного вилучення людських органів, торгівлі цими органами або торгівлі людьми з метою їх вилучення, боротьби з такими діяннями і покарання за них, а також щодо захисту жертв (Резолюция 71/322 «Усиление и поощрение эффективных мер и международного сотрудничества в сфере донорства и трансплантации органов с целью препятствовать и противодействовать торговле людьми для изъятия органов и торговле человеческими органами», 2017).

Отже, резолюція 71/322 містить ставлення та позицію ООН щодо незаконного вилучення людських органів, торгівлі цими органами або торгівлі людьми з метою їх вилучення та встановлює низку заходів, які рекомендує державам здійснити. Необхідно враховувати рекомендаційну природу резолюцій, яка не створює зобов'язань для держав-членів ООН, хоча демонструє тенденції, що відбуваються у міжнародному співтоваристві щодо регулювання трансплантації органів і / або тканин, клітин.

Нестача донорів для трансплантації та кількість пацієнтів, яким необхідна пересадка органів і / або тканин, клітин постійно збільшується. Саме з цієї причини зростає транснаціональна злочинність у сфері торгівлі органами і / або тканинами, клітинами людини. Торгівля людьми 3 метою вилучення органів і торгівля органами людини є злочинами, які шкодять і перешкоджають здійсненню прав людини та основних свобод і тягнуть за собою серйозні наслідки для здоров'я людини. Термін «торгівля людьми» розкритий у Протокол про попередження і припинення торгівлі людьми, особливо жінками і дітьми, і покарання за неї, що доповнює Конвенцію Організації Об'єднаних Націй проти транснаціональної організованої злочинності від 15 листопада 2000 року та означає «здійснювані з метою експлуатації вербування, перевезення, передачу, приховування або одержання людей шляхом загрози силою або ії застосування або ін- 
ших форм примусу, викрадення, шахрайства, обману, зловживання владою або уразливістю положення, або шляхом підкупу, у вигляді платежів або вигод, для одержання згоди особи, яка контролює іншу особу. Експлуатація включає, як мінімум, експлуатацію проституції інших осіб або інші форми сексуальної експлуатації, примусову працю або послуги, рабство або звичаї, подібні з рабством, підневільний стан або вилучення органів» (Протокол про попередження і припинення торгівлі людьми, особливо жінками і дітьми, і покарання за неї, що доповнює Конвенцію Організації Об'єднаних Націй проти транснаціональної організованої злочинності, 2000).

Питання торгівлі людьми з метою вилучення органів і торгівлі органами людини неодноразово піднімалися в ООН. ООН констатувала, що злочинні групи використовують людську потребу, злидні й нестатки і тяжке становище людей для торгівлі органами людини і торгівлі людьми 3 метою вилучення органів (Резолюция 73/189 «Усиление и поощрение эффективных мер и международного сотрудничества в сфере донорства и трансплантации органов в целях предупреждения и пресечения торговли людьми для изъятия органов и торговли человеческими органами», 2018).

Необхідно зазначити, що комерційна купівля-продаж органів людини заборонена майже у всіх державах-членах ООН. Торгівля людьми 3 метою вилучення органів і торгівля органами людини сильно позначаються на здоров'я людей, що продають свої органи, а також на здоров'ї жертв торгівлі людьми з метою вилучення органів, а також на реципієнтах органів, отриманих при таких обставинах. і що обидва ці злочини можуть становити загрозу для здоров'я населення. Торгівля людьми з метою вилучення органів і торгівля органами людини в деяких випадках навіть підривати недоторканність і функціонування систем охорони здоров’я (Резолюция 73/189 «Усиление и поощрение эффективных мер и международного сотрудничества в сфере донорства и трансплантации органов в целях предупреждения и пресечения торговли людьми для изъятия органов и торговли человеческими органами», 2018).

Для боротьби $з$ торгівлею людьми 3 метою вилучення органів і торгівлею органами людини необхідно посилювати локальне, регіональне та універсальне міжнародне співробітництво, у тому числі, і правове з метою ефективного попередження і припинення торгівлі людьми для вилучення органів і торгівлі органами людини. Також слід не допускати надання притулку особам, які беруть участь 
у транснаціональній організованій злочинній діяльності, та піддавати таких осіб судовому переслідуванню за вчинені ними злочини.

Найефективнішим механізмом боротьби з торгівлею людьми 3 метою вилучення органів і торгівлею органами людини є прийняття відповідних законодавчих та правозастосовних заходів на національному рівні з врахуванням міжнародних зобов'язань держав та міжнародних стандартів, перш за все, ООН та Всесвітньої організації охорони здоров'я. Основними міжнародними стандартами у сфері боротьби з торгівлею людьми з метою вилучення органів і торгівлею органами людини є Конвенція Організації Об'єднаних Націй проти транснаціональної організованої злочинності та Протокол про попередження і припинення торгівлі людьми, особливо жінками і дітьми, і покарання за неї, що доповнює Конвенцію Організації Об'єднаних Націй проти транснаціональної організованої злочинності.

Резолюція 73/189 «Посилення і заохочення ефективних заходів і міжнародного співробітництва в сфері донорства та трансплантації органів 3 метою попередження і припинення торгівлі людьми для вилучення органів і торгівлі людськими органами» від 17 грудня 2018 року вказує на схожі заходи, що визначені у Резолюції 71/322, які державі повинні здійснити задля попередження і припинення торгівлі людьми для вилучення органів і торгівлі людськими органами. Приділяється увага прийняттю відповідних нормативно-правових актів або внесенню змін до законодавчої бази, в тому числі, якщо це доцільно, шляхом іiї перегляду, доопрацювання або виправлення, 3 метою попередження і припинення торгівлі людьми для вилучення органів і торгівлі органами людини, включаючи введення кримінальної відповідальності за цю практику і введення положень, покликаних забезпечити притягнення винних до відповідальності. Необхідність включення етичного компоненту також міститься у Резолюції 73/189 щодо імплементації етичних норм до законодавства держав, що регламентує донорство органів.

Заборона передачі органів дитини за винагороду міститься в статті 3 Факультативного протоколу до Конвенції про права дитини щодо торгівлі дітьми, дитячої проституції і дитячої порнографії від 1 січня 2000 року. Отже, відповідно до положень статті 3 Факультативного протоколу 2000 року кожна держава-учасниця забезпечує, щоб передача органів дитини за винагороду були повною мірою охоплені ії кримінальним або карним правом, незалежно від того, чи були ці злочини вчинені на національному або 
транснаціональному рівні, або в індивідуальному чи організованому порядку. Проблема незаконної торгівлі органами та тканинами дітей і часті випадки викрадення дітей висвітлювалися в доповіді Спеціального доповідача ООН з питання про торгівлю дітьми, дитячої проституції і дитячої порнографії Хуан Мігель Петіт (Члены Совета по правам человека обсудили проблему торговли органами и тканями детей, 2007). Органи і тканини людини стають предметом торгівлі з різних причин, наприклад, їх можна використовувати для генетичних досліджень, релігійних або магічних обрядів, але в основному їх продають з метою трансплантації. «Завдяки стрімкому прогресу медицини і техніки ефективність трансплантації органів постійно зростає. При цьому, однак, продовжує збільшуватися розрив між пропозицією органів і попитом на них. Так, попит хворих на трансплантат настільки великий, а можливості медицини в плані трансплантації настільки зросли, що нестача органів неминуча», - зазначається в Доповіді Хуана Мігель Петіта (Члены Совета по правам человека обсудили проблему торговли органами и тканями детей, 2007). Також в Доповіді Спеціального доповідача ООН з питання про торгівлю дітьми, дитячої проституції і дитячої порнографії вказується, що в останні роки міжнародні кримінальні організації відкривають для себе прибутковість цього нового ринку, а торгівлю органами все частіше називають «трансплантаційний туризмом» (Члены Совета по правам человека обсудили проблему торговли органами и тканями детей, 2007).

Слід зазначити, що ще в 2009 році ООН і Рада Європи пропонували розробити міжнародну конвенцію щодо заборони торгівлі людськими органами і тканинами. У спільному досліджені, підготовленому Радою Європи та ООН 13 жовтня 2009 році в ООН вказувалося, що є необхідною Міжнародна конвенція, яка забороняє торгівлю органами, тканинами і клітинним матеріалом людини (ООН и Совет Европы предлагают разработать международную конвенцию по запрещению торговли человеческими органами и тканями, 2009). Автори дослідження вважають, що проблема торгівлі органами набула глобального характеру, де одним з ії проявів став «трансплантаційний туризм», коли багаті пацієнти виїжджають для пересадки органів в держави, де права донора ніяк не захищені. У доповіді наголошувалося, що основою будь-якого законодавства про пересадку органів має стати повна заборона на отримання фінансової вигоди в результаті використання людського тіла або його частин (ООН и Совет Европы предлагают разработать международ- 
ную конвенцию по запрещению торговли человеческими органами и тканями, 2009).

Отже, трансплантація органів і / або тканин, клітин може слугувати як компонент у реалізації права на здоров'я, а може бути одним з найсерйозніших порушень прав людини. Від блага до злочину, це дві медалі одного явища. Саме ці дві кардинально різні сторони вимагають імперативного міжнародно-правового регулювання задля забезпечення прав людини від права на здоров'я до права на охорону від свавільної трансплантації, торгівлі органами.

\section{תimepamypa:}

В Вене по инициативе Беларуси принята резолюция ООН о пресечении торговли людьми с целью изъятия органов (2016). Hobocmu ООН. URL: https://news.un.org/ru/story/2016/05/1285811

Доклад Генерального секретаря. Предупреждение незаконного оборота органов человека, борьба с ним и наказание за него. Вена, 24-28 апреля 2006 года. ООН E/CN.15/2006/10. URL: http://daccessdds.un.org/doc/ UNDOC/GEN/V06/513/19/PDF/V0651319. pdf?OpenElement

ООН и Совет Европы предлагают разработать международную конвенцию по запрещению торговли человеческими органами и тканями (2009). Hовости OOH. URL: https://news.un.org/ru/ story/2009/10/1152901

Протокол про попередження $і$ припинення торгівлі людьми, особливо жінками і дітьми, і покарання за неї, щуо доповнюе Конвениію Організаціі Об'єднаних Націй проти транснаціональної організованої злочинності від 15 листопада 2000 року. Офіиійний сайт Верховної Ради України. URL: https://zakon.rada.gov.ua/laws/show/995_791/card2\#Card

Резолюиия 71/322 "Усиление и поошрение эфффективных мер и международного сотрудничества $b$ сорере донорства и трансплантаиии органов с ијелью препятствовать и противодействовать торговле людьми для изъятия органов и торговле человеческими органами» от 8 сентября 2017 года. A/RES/71/322. eSubscription to United Nations Documents. URL: https://undocs.org/ru/A/RES/71/322

Резолюиия 73/189 "Усиление и поошрение эфффективных мер и международного сотрудничества $b$ сорере донорства и трансплантаиии органов в иелях предупреждения и пресечения торговли людьми для изъятия органов и торговли человеческими органами» от 17 декабря 2018 года. A/RES/73/189. eSubscription to United Nations Documents. URL: https://undocs.org/pdf?symbol=ru/A/RES/73/189 
Совгиря, О. В., Янчук, А. О. (2018). Право на життя: сучасний медичний та правовий контекст. Світ медицини та біологї̈, 1 (63), 216-223.

Хендель, Н. В. (2014). Міжнародно-правове регулювання співробітниитва держав у сфрері охорони здоров'я: дис. ... канд. юрид. наук: 12.00.11 / Національний університет «Одеська юридична академія». Одеса.

Члены Совета по правам человека обсудили проблему торговли органами и тканями детей (2007). Новости OOH. URL: https:/ / news. un.org/ru/story/2007/03/1103191

\section{References:}

Chleny Soveta po pravam cheloveka obsudili problemu torgovli organami i tkanyami detey (2007) [Members of the Human Rights Council discussed the issue of trafficking in organs and tissues of children (2007)]. Novosti OON [UN News]. URL: https://news.un.org/ru/story/2007/03/1103191. [in Russian].

Doklad Generalnogo sekretarya. Preduprezhdeniye nezakonnogo oborota organov cheloveka. borba s nim i nakazaniye za nego. Vena. 24-28 aprelya 2006 goda. [Report of the Secretary-General. Prevention of illegal circulation of human organs, the fight against him and punishment for him. Vienna, April 24-28, 2006]. OON E/CN.15/2006/10. URL: http://daccessdds.un.org/ doc/UNDOC/GEN/V06/513/19/PDF/V0651319. pdf?OpenElement. [in Russian].

Khendel', N. V. (2014). Mizhnarodno-pravove rehulyuvannya spivrobitnytstva derzhav u sferi okhorony zdorov"ya: dys. ... kand. yuryd. nauk: 12.00.11 / Natsional'nyy universytet "Odes'ka yurydychna akademiya" [International legal regulation of the cooperation of states in the field of health care: diss. ... for PhD in law. Specialty: 12.00.11 / National University "Odessa Law Academy"]. Odesa. [in Ukrainian].

OON i Sovet Evropy predlagayut razrabotat mezhdunarodnuyu konventsiyu po zapreshcheniyu torgovli chelovecheskimi organami i tkanyami (2009) [The UN and the Council of Europe propose the development of an international convention on the prohibition of trafficking in human organs and tissues (2009)]. Novosti OON [UN News]. URL: https://news.un.org/ru/story/2009/10/1152901. [in Russian].

Protokol pro poperedzhennya i prypynennya torhivli lyud'my, osoblyvo zhinkamy i dit'my, i pokarannya za neyi, shcho dopovnyuye Konventsiyu Orhanizatsiyi 
Ob"yednanykh Natsiy proty transnatsional'noyi orhanizovanoyi zlochynnosti vid 15 lystopada 2000 roku [Protocol on the Prevention, Suppression and Punishment of Trafficking in Persons, Especially Women and Children, supplementing the United Nations Convention against Transnational Organized Crime of 15 November 2000]. Ofitsiynyy sayt Verkhovnoyi Rady Ukrayiny [Official site of the Verkhovna Rada of Ukraine]. URL: https://zakon.rada.gov.ua/laws/show/995_791/card2\#Card. [in Ukrainian].

Rezolyutsiya 71/322 "Usileniye i pooshchreniye effektivnykh mer $i$ mezhdunarodnogo sotrudnichestva $v$ sfere donorstva i transplantatsii organov s tselyu prepyatstvovat $i$ protivodeystvovat torgovle lyudmi dlya izyatiya organov $i$ torgovle chelovecheskimi organami» ot 8 sentyabrya 2017 goda. A/RES/71/322 [Resolution 71/322, "Strengthening and Encouraging Effective Measures and International Cooperation in the Field of Organ Donation and Transplantation with the Purpose of Preventing and Counteracting Human Trafficking for Organ Removal and Human Organ Trafficking" of September 8, 2017. A / RES / 71/322]. eSubscription to United Nations Documents. URL: https:/ / undocs.org/ru/A/RES/71/322. [in Russian].

Rezolyutsiya 73/189 "Usileniye $i$ pooshchreniye effektivnykh mer $i$ mezhdunarodnogo sotrudnichestva $v$ sfere donorstva i transplantatsii organov $v$ tselyakh preduprezhdeniya i presecheniya torgovli lyudmi dlya izyatiya organov $i$ torgovli chelovecheskimi organami» ot 17 dekabrya 2018 goda. A/RES/73/189 [Resolution 73/189 "Strengthening and promoting effective measures and international cooperation in the field of organ donation and transplantation in order to prevent and combat trafficking in persons for organ removal and trafficking in human organs" of December 17, 2018. A / RES / 73/189]. eSubscription to United Nations Documents. URL: https:// undocs.org/pdf?symbol=ru/A/RES/73/189. [in Russian].

Sovhyrya, O. V., Yanchuk, A. O. (2018). Pravo na zhyttya: suchasnyy medychnyy ta pravovyy kontekst [The right to life: current medical and legal context]. Svit medytsyny ta biolohiyi [World of Medicine and Biology], 1 (63), 216-223. [in Ukrainian].

$V$ Vene po initsiative Belarusi prinyata rezolyutsiya OON o presechenii torgovli lyudmi s tselyu izyatiya organov (2016) [In Vienna, on the initiative of Belarus, a UN resolution was adopted on the suppression of trafficking in persons with the aim of removing organs (2016)]. Novosti OON [UN News]. URL: https:// news.un.org/ru/story/2016/05/1285811. [in Russian]. 


\section{Анотачія}

Пасечник О. В. Стандарти організачіӥ об'єднаних націй у сфері трансплантації органів і/або тканин, клітин. - Стаття.

У статті проаналізований універсальний рівень правового регулювання трансплантаціїорганіВ і/або тканин, клітин у рамках Організації Об'єднаних Націй. Досліджено положення «м'якого права» Організації Об'єднаних Націй у сорері трансплантації органів і / або тканин, клітин. Розкриті положення Резолюиії Генеральної Асамблеї ООН 71/322 «Посилення $і$ заохочення ефрективних заходів і міжнародного співробітництва $b$ сфері донорства та трансплантації органів з метою перешкоджати і протидіяти торгівлі ююдьми для вилучення органів і торгівлі ююдськими органами» та Резолюиії Генеральної Асамблеї 73/189 «Посилення і заохочення ефрективних заходів $i$ міжнародного співробітництва в сорері донорства та трансплантації органів зметою попередження і припинення торгівлі людьми для вилучення органів і торгівлі людськими органами». Розглянуті сучасні виклики у міжнародноправовому співробітництві у сорері регулювання трансплантації органів i / або тканин, клітин. У статті звертається увага на діяльність Спеціального доповідача ООН з питання про торгівлю дітьми, дитячої проституції і дитячої порнографії щодо питань трансплантації органів i / або тканин, клітин. Аналізуеться положення Факультативного протоколу до Конвениії про права дитини щодо торгівлі дітьми, дитячої проституції і дитячої порнографрії від 1 січня 2000 року, які застосовуються до трансплантації органів і/ або тканин, клітин. Проаналізована пропозиція ООН і Ради Європи щуодо розробки міжнародної конвенції з заборони торгівлі людськими органами і тканинами. Доведено, що трансплантація органів i / або тканин, клітин може слугувати як компонент у реалізації права на здоров'я, а може бути одним з найсерйозніших порушень прав людини. Від блага до злочину, це дві медалі одного явища. Саме изі дві кардинально різні сторони вимагають імперативного міжнародно-правового регулювання задля забезпечення прав людини від права на здоров'я до права на охорону від свавільної трансплантацї, торгівлі органами. Встановлено, що на універсальному рівні відсутні зобов' язуючі норми у сфері трансплантації органів i /або тканин, клітин.

Ключові слова: трансплантація органів і / або тканин, клітин, Організація Об'єднаних Націй, Комісія ООН із запобігання злочинності та кримінального правосуддя, право на здоров'я. 